\title{
UPRAVLJANJE INFORMACIJAMA U GRAĐEVINSKOM POSLOVNOM SUSTAVU
}

\author{
Marko Novak \\ Ured ovlaštenog inženjera Marko Novak, Požega, dipl.inž.građ. \\ Ivica Završki \\ Sveučilište u Zagrebu, Građevinski fakultet, prof.dr.sc. \\ Matej Mihić \\ Sveučilište u Zagrebu, Građevinski fakultet, mag.ing.aedif., znanstveni novak
}

\begin{abstract}
Sažetak: Upravljanje poslovnim informacijama od iznimnog je značaja za uspješno poslovanje u građevinarstvu. Istraživanje, koje je temelj ovog rada, nastojalo je utvrditi koliku važnost hrvatska građevinska poduzeća u svojoj praksi pridaju ovom području, te koje metode pritom primjenjuju. Nadalje, u radu se istražuje kakva je praksa u upravljanju informacijama u državnim institucijama od kojih se očekuje da prikupljaju, obrađuju i distribuiraju poslovne informacije bitne za građevinsku gospodarsku granu. Rad također daje i preporuke za poboljšanje sustava za upravljanje poslovnim informacijama.
\end{abstract}

Ključne riječi: poslovne informacije, upravljanje informacijama, business intelligence

\section{MANAGING INFORMATION IN CONSTRUCTION BUSINESS ENTERPRISES}

\begin{abstract}
Managing the business information is of the utmost importance for a successful business in the construction industry. The research, which is the basis of this paper, has tried to determine how much importance do the Croatian construction companies give to this problem in real life and which methods they apply. Furthermore, the paper researches what is the state of information management in public institutions, which are expected to gather, process and distribute that business information to the construction industry as a part of the nation's economy. Recommendations on how to improve the system of information management are also given in the paper.
\end{abstract}

Key words: business information management, intelligence, business intelligence 


\section{Uvod}

Cilj svake tvrtke je da preko instrumenata upravljanja osigura stalan rast i razvitak te tako poveća svoju vlastitu vrijednost. Konkurencija i sve bolja informiranost kupaca prisiljavaju poduzeća na značajnu promjenu strateškog razmišljanja. Svaka se strategija temelji na izgradnji i održavanju konkurentske prednosti. Pri tome prednost imaju ona poduzeća čije je poslovanje zasnovano na brzom informiranju. Ubrzanim razvojem informacijskih i komunikacijskih tehnologija rješavaju se uočeni problemi u poslovanju. Korištenje informacijske tehnologije bitno smanjuje troškove proizvodnje, povećava konkurentnost i naravno, profitabilnost poduzeća, budući da se njihovim korištenjem može optimalizirati sam proizvodni proces, procesi informiranja i odlučivanja, te plasmana proizvoda na tržištu. Uz informatizaciju procesa proizvodnje sve više se i sama informacija koristi kao roba. Radi se o selekcioniranim informacijama čija poruka ima značajnu upotrebnu vrijednost, pri čemu je vrijeme potrebno za pristup ovim informacijama izuzetno kratko. Od svih informacijskih sustava koji se danas koriste u svim sferama društva, najznačajniji su informacijski sustavi koji služe za upravljanje proizvodnjom u poduzećima.

Kada govorimo o građevinarstvu, važno je reći da je i na ovome području prisutna sve oštrija konkurencija uvjetovana globalizacijom tržišta, te osobito u slučaju Republike Hrvatske, otvaranjem tržišta koje nastupa ulaskom u Europsku Uniju. Informacijske tehnologije (IT) i redizajn poslovnih procesa u građevinarstvu trebali bi biti u središtu promjena koje bi dovele građevinarstvo $u$ isti nivo sa, u tom pogledu najnaprednijim privrednim granama. Pritom je od izuzetnog značenja način strukturiranja informacija u odnosu na nivo upravljačkog sustava kojemu su namijenjene, te pravovremenost njihova dostavljanja na mjesta gdje su neophodne. Ovaj skup aspekata obično se naziva Business Intelligence.

Business intelligence se u hrvatskom jeziku prevodi na mnogo načina, ovisno o autoru i djelu, ali je ipak u domaćoj literaturi, kao i u našem okruženju, najčešće korišten prijevod „poslovna inteligencija“ koji će i u ovome članku biti korišten. Također se koriste termini „upravljanje poslovnim informacijama“, „poslovno obavješćivanje“, „poslovno istraživanje“ [1], „poslovno izvještavanje“, „poslovne izvjesnice“ [2], „poslovno-obavještajna aktivnost“ [3], što je prijevod koji možda najbolje oslikava smisao business intelligenca.

Kao definiciju poslovne inteligencije mogli bismo navesti onu Kalkota R. i Robinsona M. koja kaže kako je „pretvaranje podataka u znanje posao poznat pod imenom poslovna inteligencija (BI - business intelligence). To predstavlja skupinu nadolazećih aplikacija, dizajniranih da organiziraju i strukturiraju transakcijske podatke poduzeća, tako da ih se može analizirati i koristiti na dobrobit tvrtkinih operacija i podrške odlučivanju" [4].

Drugi autori [5] pak zaključuju da je „business intelligence (poslovno - obavještajna aktivnost) obavještajna aktivnost u poslovnom svijetu koju planiraju, organiziraju i provode poslovni subjekti, pri čemu ta aktivnost podrazumijeva proces legalnog prikupljanja javnih i svima dostupnih podataka etičnim sredstvima, njihovu analizu i pretvaranje u gotove poslovno - obavještajne analize (znanje) radi pružanja potpore čelništvu poslovnog subjekta s ciljem donošenja i realizacije što kvalitetnijih poslovnih odluka usmjerenih na očuvanje postojeće pozicije poslovnog subjekta u poslovnom okruženju, izbjegavanje bilo kakvih prijetnji i u konačnici na ukupni kvalitativni napredak poslovnog subjekta".

\section{Metodologija istraživanja primjene sustava upravljanja poslovnim informacijama}

\subsection{Uvod u metodologiju istraživanja}

Izvođačima građevinskih radova nameću se zahtjevi za upravljanjem i praćenjem procesa građenja, stanja skladišta i zahtjevi za kvalitetnom uslugom isporuke. Primjenom suvremenih informacijskih tehnologija neophodno je osigurati informacije o realizaciji projekta tijekom cijelog ciklusa i kroz cijeli logistički lanac. Informacijske tehnologije i redizajn poslovnih procesa u građevinarstvu moraju biti u središtu promjena koje bi građevinarstvo trebale dovesti u isti tehnološki nivo s drugim gospodarskim granama.

Kako bi se na stvarnim uzorcima iz hrvatske prakse provjerilo stanje stvari, provedeno je istraživanje stupnja primjene sustava upravljanja poslovnim informacijama u hrvatskim građevinskim poduzećima, shvaćanje važnosti tog sustava u suvremenom poslovnom okruženju te odnos upravljačkih struktura unutar poslovnih subjekata prema istome. Prateći iste smjernice, provedeno je $\mathrm{i}$ istraživanje načina rada pojedinih državnih institucija na planu prikupljanja, obrade i daljnje distribucije poslovnih informacija, koje bi bile korisne kod 
donošenja strateških poslovnih odluka gospodarskih subjekata u hrvatskom građevinarstvu, kroz središnji ured ili agenciju na državnom nivou.

\subsection{Metodologija istraživanja}

Početna točka istraživanja bila je studij domaće i međunarodne literature koja se bavi tematikom upravljanja poslovnim informacijama. Nakon provedene analize literature i temeljem ukupnih teoretskih spoznaja sačinjeni su alati za prikupljanje informacija o načinu rada pojedinih državnih institucija u pogledu prikupljanja, analize i distribucije podataka značajnih za odlučivanje u poslovanju građevinskih gospodarskih subjekata. Uzimajući u obzir da je broj sudionika u uzorku istraživanja bio relativno mali, provedeno je istraživanje pomoću unaprijed pripremljenog polustrukturiranog intervjua, tj. kroz popunjavanje anketnog upitnika i razgovor o predmetnoj tematici s ovlaštenim osobama unutar državnih institucija.

Anketni upitnik koncipiran je tako da sadrži pitanja kojima se analizira shvaćanje važnosti postojanja središnjeg sustava, na državnom nivou, koji se bavi ovom tematikom te odnos prema tom sustavu unutar državnih institucija. Kriterij povezanosti institucija s gospodarskom granom ocijenjen je kao izuzetno važan jer bi ta povezanost trebala podrazumijevati i poznavanje potreba građevinarstva i imati i najveći utjecaj na poboljšanje opskrbljivanjem kvalitetnim poslovnim informacijama te usmjeravanjem prema korištenju modernih sustava za upravljanje poslovnim informacijama. Jednako važan čimbenik kod izbora sugovornika bila su i saznanja do kojih se došlo kroz studij literature s ovog područja, kao i kroz diskusije o ovoj temi. Iz navedenoga je proizašla ideja o uspoređivanju modela sustava upravljanja poslovnim informacijama koji funkcionira u Republici Hrvatskoj sa sustavima koji egzistiraju u zemljama s razvijenijim gospodarstvom, jer u većini zemalja koje se ističu u svjetskim okvirima postoje središnji sustavi na državnoj razini zaduženi za tematiku upravljanja poslovnim informacijama. U tim sustavima kroz analize podataka i oni postaju znanje te se onda u finalnome obliku distribuiraju gospodarstvu.

Da bi se istražio način i stupanj primjene sustava upravljanja poslovnim informacijama u hrvatskim građevinskim poslovnim subjektima, bilo je potrebno odabrati daleko širi uzorak ispitanika. Uzimajući u obzir navedenu činjenicu, izrađen je strukturirani anketni upitnik. Taj upitnik, namijenjen odgovornim osobama u građevinskim poduzećima iz prakse, zamišljen je tako da se kroz odgovore na pitanja dođe do saznanja koliko se važnosti pridaje sustavu upravljanja poslovnim informacijama u suvremenome poslovnom okruženju te kakav je odnos prema njemu unutar hrvatskih građevinskih poduzeća. Svi rezultati iz sljedećeg poglavlja korišteni su iz magistarskog rada prvog autora [6].

\section{Primjena metodologije istraživanja}

\subsection{Anketa provedena u građevinskim poduzećima $\mathrm{RH}$}

Anketni upitnici popraćeni anketnim pismima poslani su na 110 adresa hrvatskih tvrtki kojima je područje djelovanja graditeljstvo. Važeće odgovore na anketu poslalo je 39 tvrtki. Uzimajući u obzir navedeno, možemo zaključiti da je istraživanje, u statističkom smislu gledano, provedeno na reprezentativnom uzorku koji odražava stvarno stanje primjene sustava upravljanja poslovnim informacijama u građevinskim poslovnim subjektima Republike Hrvatske. U istraživanju su zastupljena velika, srednje velika i mala poduzeća, postignuta je i zastupljenost po geografskoj lokaciji i prema vrsti djelatnosti. Prema vrsti djelatnosti najviše su zastupljena izvođačka poduzeća, naravno uz prisutnost i poduzeća koja se bave projektiranjem, konzaltingom i isporukom građevinskih materijala.

\subsection{Rezultati obrađenih podataka iz anketnih upitnika upućenih građevinskim poduzećima u RH}

Kako je jedan od ciljeva bio istražiti poduzeća različitih veličina, anketom je obuhvaćeno najviše tvrtki srednje veličine. Najveći broj istraživanih poduzeća ostvaruje godišnje prihode od 2,0 -10,0 mil. eura, a više od četvrtine ispitanih poduzeća ima prihode na razini iznad 50,0 mil eura. Ovo pokazuje da se uspjelo postići svrhu ispitivanja i njime pokriti razne veličine poduzeća. $61,5 \%$ anketiranih tvrtki uopće ne ostvaruje prihode izvan granica Republike Hrvatske, tj. poslovno ne djeluje u inozemstvu. Ostale tvrtke su poslovno aktivne i izvan područja RH 
te na taj način ostvaruju od cca $3 \%$ do $13 \%$ svog prihoda na inozemnom tržištu. $U$ anketiranim poduzećima prevladava linijski model organizacijske strukture koji egzistira u 46,2\% poduzeća. Funkcijski model je po zastupljenosti odmah iza njega, a matrični model, te model po poslovnim procesima, zastupljeni su gotovo jednako.

Prosječna životna dob menadžera i rukovodećeg kadra u anketiranim hrvatskim građevinskim poduzećima kreće između trideset i pedeset godina starosti što je povoljno, jer u pravilu mlađa upravljačka struktura lakše i brže usvaja moderne IT. Između 40 i 50 \% menadžera i rukovodećeg kadra ispitanih poduzeća osposobljeno je koristiti se postojećim informacijskim sustavom unutar poduzeća. Taj postotak nikako nije zadovoljavajući te je pokazatelj da se postojeće stanje mora popraviti radi što efikasnije iskoristivosti postojećih sustava, ali i zbog što lakšeg uvođenja modernih sustava upravljanja poslovnim informacijama u hrvatska građevinska poduzeća.

Pozitivno je što više od $64 \%$ ispitanika (slika 1) redovito prikuplja, analizira te sprema poslovne informacije iz vlastitih iskustava s projekata u kojima su ranije sudjelovali, kako bi in kasnije u odgovarajućem trenutku mogli koristiti, ali ipak u $36 \%$ poduzeća takva praksa nije prisutna. Naravno, svrha prikupljenih podataka i informacija je ta da se one stručno analiziraju, nakon čega postaju znanje, tj. kapital tvrtke koja to znanje posjeduje. Zatim se pohrane u određene baze podataka te u pravome trenutku distribuiraju na upravljačku razinu koja to znanje treba.

Iz rezultata istraživanja vidljivo je da $38,5 \%$ (slika 1) poduzeća ima propisanu proceduru kojom se regulira način prikupljanja podataka s područja interesa poduzeća, a 43,6\% poduzeća izjavljuje da ima propisanu formalnu proceduru koju primjenjuju povremeno. Zabrinjavajuća činjenica je ta da gotovo $18 \%$ poduzeća ne primjenjuje nikakvu formalnu proceduru koja regulira prikupljanje poslovnih informacija. U 48,7\% poduzeća postoji integrirana poslovna funkcija zadužena za upravljanje poslovnim informacijama što je pozitivno (slika 1), ali je zabrinjavajuće to što je $51,3 \%$ posto ispitanika izjavilo da u njihovim poduzećima ne postoji poslovna funkcija koja je zadužena za upravljanje poslovnim informacijama. To upućuje na zaključak da se ne razumije važnost ove poslovne funkcije ili ne prepoznaje njena svrha, mogućnosti i prilike koje se pružaju njenom pravilnom integracijom u poslovni sustav.

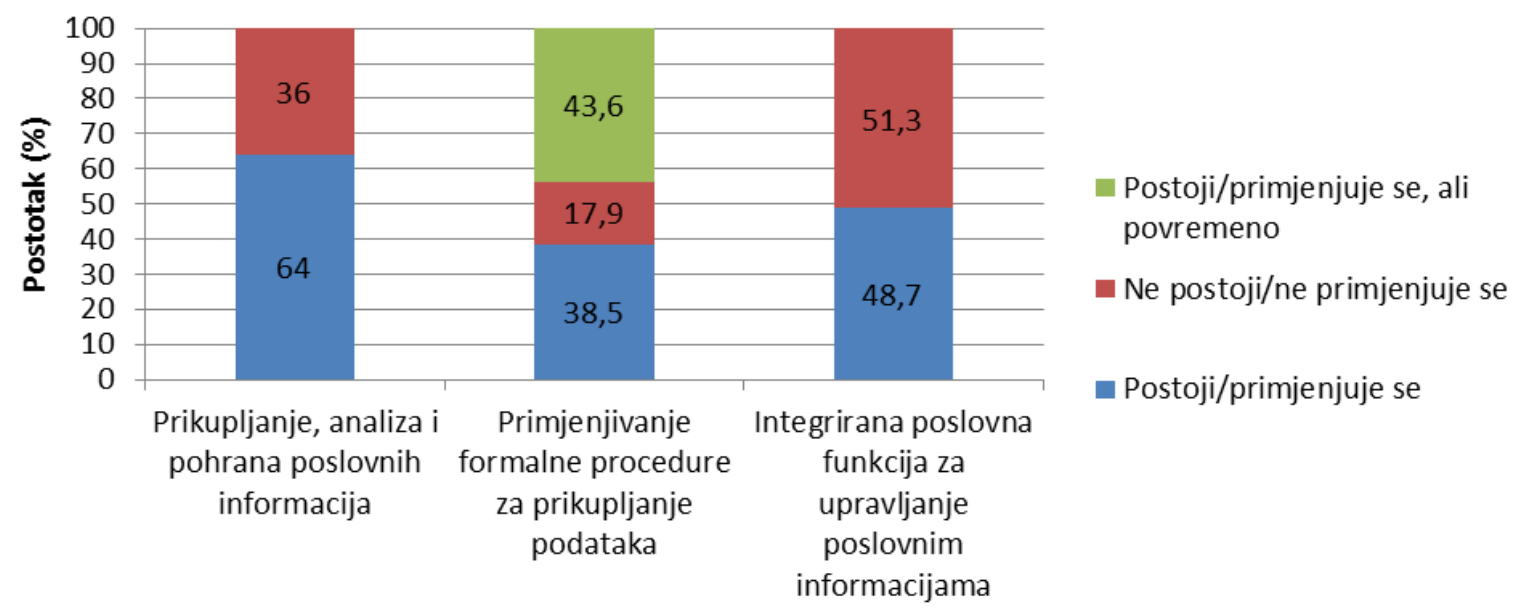

\section{Slika 1 - Upravljanje poslovnim informacijama}

U hrvatskim građevinskim poduzećima egzistiraju različite procedure odlaganja podataka, od tradicionalnih arhiva koje još uvijek koristi oko $70 \%$ poduzeća (slika 2), preko elektronskih baza podataka koje su u upotrebi kod gotovo $80 \%$ poduzeća, do on-line skladišta podataka koja se koriste u $28 \%$ poduzeća. Za uspješnu i što lakšu integraciju sustava upravljanja poslovnim informacijama u poslovanje poduzeća, najpovoljniji način odlaganja podataka su on-line skladišta podataka jer je u njima najlakše postići jednoznačnost i standardiziranost informacije, a i podatci se iz njih najlakše i najbrže zahvaćaju prilikom kasnije analitičke obrade i kreiranja traženih izvještaja od strane upravljačkih struktura. U hrvatskim građevinskim poduzećima koriste se tehnike skladištenja u obliku unaprijed predviđenih formulara. $46.2 \%$ poduzeća (slika 2 ) je izjavilo da upotrebljavaju ovu tehniku skladištenja, ali jednako toliko ih je izjavilo da nemaju nikakve unaprijed propisane formulare. $28,2 \%$ poduzeća koristi skladištenje u obliku pisanog izvješća, među kojima je više od $40 \%$ poduzeća izjavilo da ne postoji unaprijed definirani oblik u kojemu skladište podatke, te da se kod njih koristi takav način pohranjivanja 
podataka. Naravno, najbolja tehnika skladištenja podataka je kroz propisan oblik - formular, jer je na taj način osigurano da informacije u skladište podataka uvijek ulaze standardizirane i prikazane na ujednačen način. Najlošija opcija je kada se informacije prikupljaju povremeno i nesistematizirano te još uz to skladište u proizvoljnom obliku u različitim formatima. Tako pohranjene informacije je praktično nemoguće efikasno zahvaćati kasnije, kada se za to ukaže potreba. Tada je čest slučaj da nakon nekog vremena u poduzeću i ne znaju za te podatke ili in ne mogu pronaći.

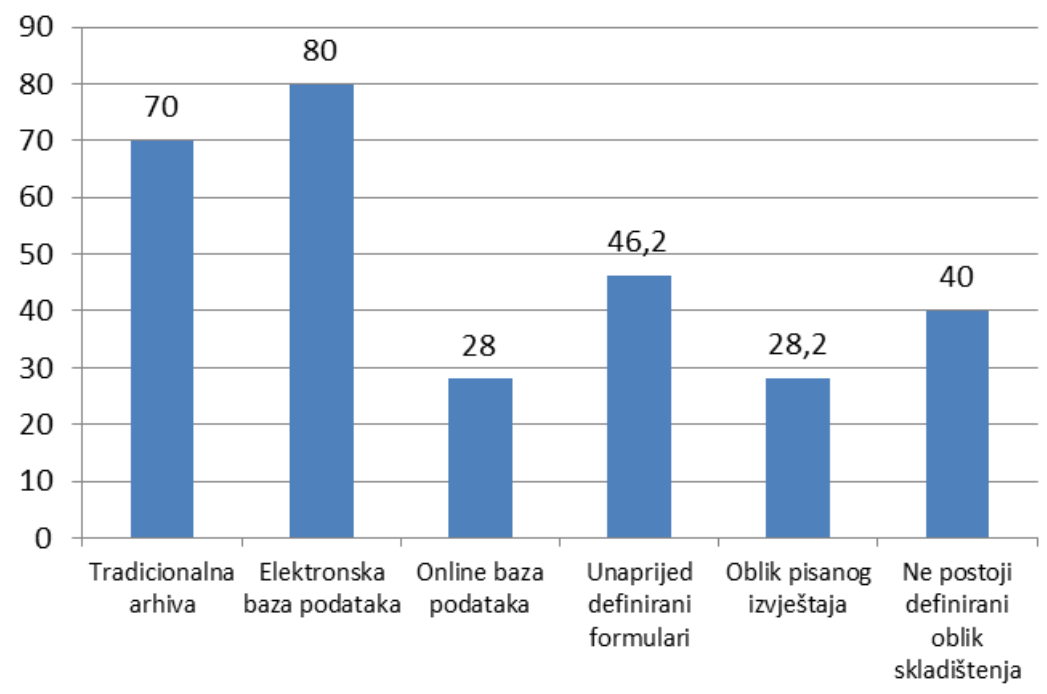

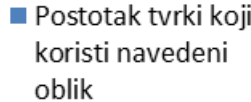

oblik

\section{Slika 2 - Skladištenje podataka}

Pozitivno je to što se može zaključiti da upravljačke strukture većine poduzeća prepoznaju moguće koristi od sustava upravljanja poslovnim informacijama, ali isto tako je vidljivo da veliki broj njih nije siguran u to što su zadaće i mogućnosti sustava upravljanja poslovnim informacijama. Najveći broj poduzeća, njih $64,1 \%$ navelo je da je najvažnije područje o kojemu prikupljaju informacije tržišni i razvojni segment, a ostale segmente je kao najvažnije naveo značajno manji dio tvrtki. Najmanje poduzeća misli da je važno prikupljati informacije iz segmenta upravljanja znanjem, što upućuje na zaključak da upravljačka struktura hrvatskih građevinskih poduzeća, u velikom broju slučajeva, nije prihvatila činjenicu da je znanje koje tvrtka posjeduje više od polovine njene vrijednosti te da nisu do kraja svjesni mogućnosti alata za upravljanje znanjem.

Važnost prikupljanja informacija o tome što rade njihovi vanjski suradnici, kooperanti ili konzultanti i njima konkurentske tvrtke, prepoznalo je oko cca 40\% (slika 3) poduzeća. Izuzetno loš stav imaju ona poduzeća koja su izjavila da uopće ne prikupljaju informacije o vanjskim suradnicima, a njih je više od $50 \%$. Stanje u kojem poduzeća ne zanimaju informacije za koga još, osim za njih, rade njihovi kooperanti, konzultanti i dr. te gdje bi mogle završiti informacije o njihovome poslovanju i poduzeću, potrebno je hitno mijenjati. Većina poslovnih subjekata ipak je u određenoj mjeri svjesna važnosti segmenta sigurnosti poslovnih informacija i na neki način se nastoji zaštititi od neovlaštenog posjedovanja njihovih povjerljivih informacija od strane trećih osoba. Naravno da određene informacije o sebi i svome poslovanju poduzeća svjesno objavljuju, ali zato što na taj način žele postići određene efekte i rezultate te zato što je to zacrtano njihovom strategijom poslovanja. Isto tako je potrebno štititi one informacije za koje uprava poduzeća misli da su kompetitivna prednost i da ne trebaju biti poznate izvan tvrtke. Samo 17,9\% (slika 3) poduzeća je izjavilo da kod njih postoji formalizirana procedura, integrirana u interne propise i pravila ponašanja tvrtke, kojom se provjerava cure li informacije te da je zaposlenicima tvrtke ta procedura poznata. Izuzetno loše stanje na tome području oslikava se kroz odgovore od $69,2 \%$ (slika 3) poduzeća koja su izjavila da takva procedura kod njih ne postoji. To znači da djelatnici tih poduzeća niti ne znaju kako bi se trebali ponašati radi zaštite informacija svoje tvrtke, ali nitko to od njih niti ne traži.

Rezultati odgovora na ovo pitanje direktno su u suprotnosti s odgovorima poduzeća na neka prethodna pitanja, gdje je 76,9\% poduzeća (slika 3) izjavilo da sigurnost poslovnih informacija drži za izuzetno važan element uspješnog poslovanja. Kako na pitanje o tome koliko zaposlenika radi unutar službe koja se bavi zaštitom poslovnih informacija većina poduzeća nije uopće odgovorila, potvrđuje se raniji zaključak da oni nemaju 
zaposlenika koji se time bavi. Na pitanje posjeduju li zaposlenici službe koja se bavi zaštitom poslovnih informacija formalnu kvalifikaciju za obavljanje te vrste poslova, čak $82,1 \%$ ispitanika nije odgovorilo, dok in je $17,9 \%$ odgovorilo potvrdno (slika 3). To nameće i potvrđuje zaključke iz odgovora na nekoliko prethodnih pitanja, a to je da je stupanj zaštite informacija u većini građevinskih poslovnih subjekata Republike Hrvatske dosta nizak.

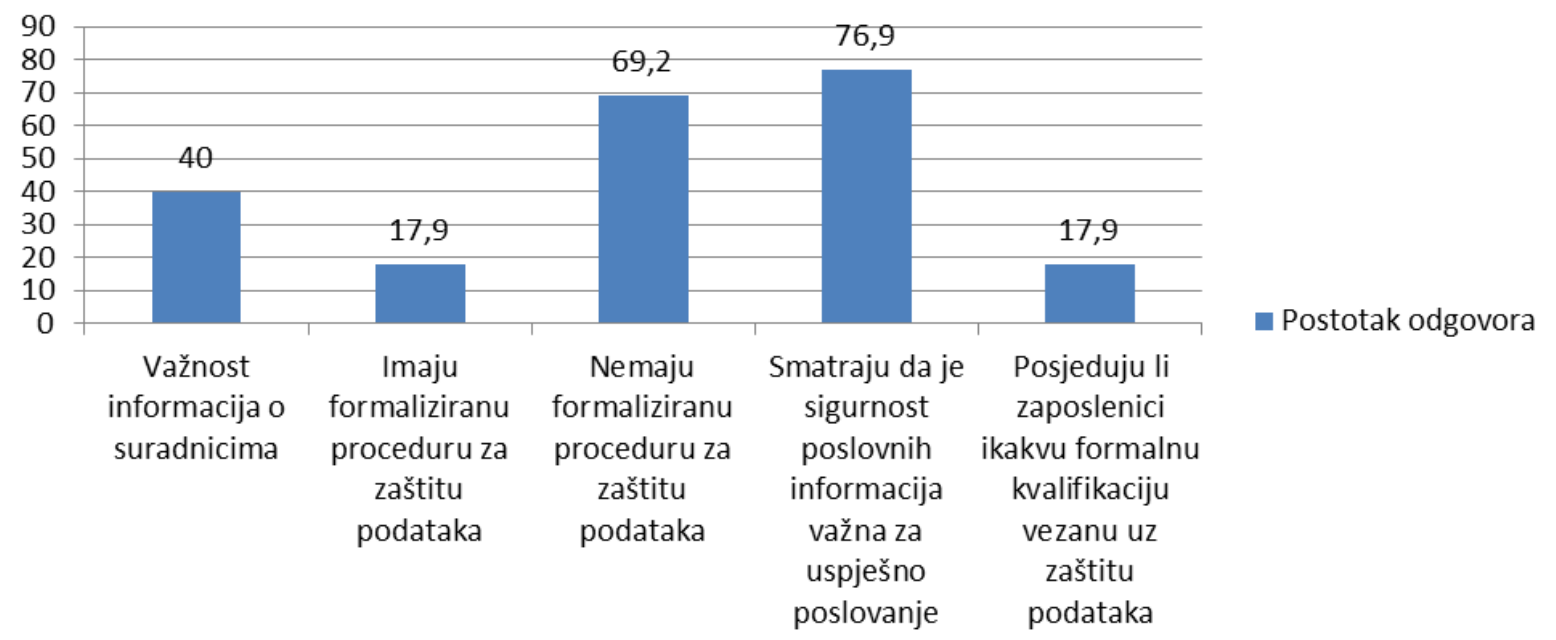

\section{Slika 3 - Zaštita poslovnih informacija}

Vidljivi su i pozitivni primjeri koji su naveli određene vidove zaštite koji se mogu klasificirati kao ozbiljniji. U većini poduzeća, njih $76,9 \%$, dali su odgovor kako misle da je tehnički aspekt sigurnosti, koji se odnosi na sigurnost informatičkih sustava i mreža te na ostale komunikacijske sustave poslovnog subjekta, najvažniji, te da su na njega fokusirani najviše prilikom izgradnje sustava zaštite i sigurnosti podataka. Njih $30,8 \%$ drži fizički aspekt sigurnosti važnim, a $41 \%$ navodi personalno - kadrovski aspekt sigurnosti kao točku fokusa. U zemljama s razvijenim gospodarstvima već je poznata činjenica da se najviše informacija izgubi prenošenjem informacija od strane vlastitih kadrova konkurenciji. Naravno, to ne znači da su ostali aspekti sigurnosti nevažni i da in treba zanemariti.

Što se zadovoljstva sustavom za upravljanje poslovnim informacijama tiče, najviše je onih koji su odgovorili da su djelomično zadovoljni sustavom upravljanja poslovnim informacijama u njihovim poduzećima, a više od $30 \%$ poduzeća je izjavilo da je potpuno zadovoljno svojim sustavima za upravljanje informacijama. Velika većina poduzeća, $(71,8 \%)$ nije dala nikakav odgovor na pitanje koji su razlozi nezadovoljstva stupnjem primjene sustava upravljanja poslovnim informacijama u njihovim poduzećima, ako neki stupanj nezadovoljstva postoji. To ukazuje na visok stupanj nezainteresiranosti i nepoznavanja vlastitog sustava, dok je samo manji broj poduzeća pravilno locirao žarišta problema i prema tamo usmjerio svoje nezadovoljstvo. Velika većina poduzeća nije dala nikakav odgovor niti na upit što bi trebalo unaprijediti, ako već jesu nezadovoljni stupnjem primjene sustava upravljanja poslovnim informacijama. Ovo nas vraća na zaključak iz odgovora na prethodno pitanje i naglašava ozbiljnost stanja na ovome području unutar hrvatskih građevinskih poduzeća. Iz odgovora se vidi da ima i svijetlih primjera koji su shvatili u kojemu smjeru je važno ići, kao primjerice poduzeće koje je odgovorilo da treba uvesti norme ISO 27001 (najraširenije međunarodne norme za informacijsku sigurnost).

Vezano uz isplativost sustava za upravljanje poslovnim informacijama, gotovo $70 \%$ ispitanika je odgovorilo da model sustava upravljanja poslovnim informacijama kakav imaju u svome poduzeću opravdava sredstva investirana u njega, iz čega bi trebalo zaključiti da su zadovoljni s njima. Iz odgovora na ovo pitanje nameće se zaključak da jedan broj poduzeća ne razumije postavke sustava upravljanja poslovnim informacijama kao ni njegovu ulogu i operativne mogućnosti pa su upravo iz tih razloga u uvjerenju kako imaju kvalitetne sustave upravljanja informacijama. Izuzetno je važno to što $84,6 \%$ poduzeća misli da bi intenzivna primjena poslovno informacijskih sustava u građevinskim poduzećima podigla razinu efikasnosti poslovanja u građevinskim poduzećima. Ovakav stav u poduzećima je izuzetno pozitivan i nameće zaključak da uprave hrvatskih građevinskih poduzeća ipak razmišljaju o ozbiljnijim investicijama u ovo područje. 


\subsection{Intervju proveden u državnim institucijama RH}

U zemljama s razvijenim gospodarstvima u europskim i svjetskim okvirima već niz godina ulažu izuzetni napori na području upravljanja poslovnim informacijama. Izuzetno važna točka pritom je da država, kroz svoje određene institucije, pruža značajnu podršku gospodarskim subjektima. U velikom broju tih zemalja postoje središnji sustavi na državnoj razini koji su zaduženi za tematiku upravljanja poslovnim informacijama. Iz navedenog je proizašla ideja o uspoređivanju modela sustava upravljanja poslovnim informacijama koji funkcionira u Republici Hrvatskoj sa sustavima koji egzistiraju u navedenim zemljama.

Na osnovi inicijalne ideje i opisanih saznanja pristupilo se odabiru adekvatnih sugovornika, tj. državnih institucija koje su najviše povezane s gospodarstvom, a samim time i građevinarstvom kao jednom od najvažnijih gospodarskih grana. U tom kontekstu je procijenjeno da bi navedeni sugovornici trebali najbolje poznavati potrebe građevinarstva, ali i imati najveći utjecaj na pokretanje pozitivnih procesa u navedenoj grani gospodarstva. Kako bi zaštitili njihove identitete, nazivi tih državnih institucija neće se spominjati.

\subsection{Rezultati obrade podataka intervjua državnih institucija RH}

Namjera je bila kroz istraživanje utvrditi postojanje sustavnosti prikupljanja poslovnih informacija na razini državnih institucija, odabranih po ranije opisanim kriterijima, koje su precizne i dovoljno pouzdane da bi naše gospodarstvo, a samim time i građevinarstvo, na njima moglo temeljiti svoje strateške poslovne odluke. Odgovori na prvo anketno pitanje kojim se istraživalo postojanje organiziranog sustava prikupljanja poslovnih informacija pokazali su različitosti u poznavanju predmetne problematike odgovornih osoba unutar anketiranih državnih institucija te u načinu razmišljanja o njoj.

Tako unutar jedne državne institucije postoji sektor za građevinarstvo i komunalno gospodarstvo koji prikuplja poslovne informacije koje su predmet interesa građevinskih poslovnih subjekata. Unutar jedne druge državne institucije tvrde da također sustavno prikupljaju poslovne informacije značajne za gospodarstvo, ali ne i za građevinarstvo. Odgovori drugih dvaju državnih institucija kažu da se podatci koji su ovdje predmet interesa prikupljaju povremeno.

Nadalje, pokušalo se utvrditi postojanje sustavnosti prikupljanja poslovnih informacija, na razini državnih institucija koje njima samima služe kao nit vodilja kod kreiranja novih zakona koji bi trebali olakšati poslovanja gospodarskim subjektima. Tri državne institucije odgovorile su da prikupljaju ovu vrstu informacija te in nastoje integrirati u buduće zakone prilikom njihova donošenja, uz napomenu četvrte da sustavnost prikupljanja podataka postoji samo kada su u pitanju informacije iz unutarnjih izvora, tj. iz njhove institucije, a kada je riječ o vanjskim izvorima onda se informacije prikupljaju povremeno, od slučaja do slučaja. Isti odgovor je dobiven i iz institucije B. Naravno, nije dobro što se informacije sistematiziraju samo unutar institucije jer opće je poznato da uz unutrašnje informacije, one iz okruženja predstavljaju ključni resurs kod donošenja bilo kakvih odluka.

Daljnji logičan slijed je bio utvrditi postoji li unutar bilo koje od anketiranih državnih institucija organizacijska jedinica koja sistematski prikuplja poslovne informacije. Riječ je o primjerice Business Intelligence odjelu koji bi imao instaliranu opremu i kadrove koji su osposobljeni obavljati predmetne zadaće. Odgovor iz prve državne institucije je da unutar njihove institucije postoji takav odjel, ali ponovno uz napomenu da on prikuplja informacije interesantne za gospodarstvo, ali ne i za građevinarstvo. Predstavnik druge institucije je, kroz svoj odgovor da svatko prikuplja informacije sam iz svog područja interesa, pokušao ostaviti dojam da se kod njih ozbiljno radi na tome polju. Ali sam odgovor kaže da unutar te institucije ne postoji ustrojena organizacijska jedinica koja se ozbiljno i stručno bavi ovom tematikom. Predstavnik treće institucije je vrlo korektno odgovorio da takav odjel nije integriran unutar njihove institucije, iako smatra da na državnoj razini svakako treba uspostaviti neki vid centralizacije ovakvog sustava. Iz četvrte institucije stigao je odgovor da imaju centar za informacije unutar te institucije.

Ako u svome sastavu nemaju integrirane odjele za prikupljanje, analizu i distribuciju poslovnih informacija, važno je bilo utvrditi na koje načine državne institucije do njih dolaze te radi li to netko drugi za njih. Četvrta državna institucija dala je odgovor da oni predmetne informacije dobivaju kroz službene kanale sigurnosnih službi i diplomatskih predstavništava, što je i logično organiziran slijed događaja. Iz prve institucije došao je isti takav odgovor, ali sa križanjem sigurnosnih službi iz ponuđenog odgovora te dodatka „i kontaktima s ostalim vladinim i nevladinim institucijama". Ovaj način distribuiranja poslovnih informacija iz inozemstva prema matičnim zemljama dosta je često u upotrebi, jer se sustavi prikupljanja i distribuiranja poslovnih informacija u gospodarski razvijenim 
zemljama najčešće oslanjaju na mreže njihovih diplomatskih predstavništava i sigurnosnih službi, ako je riječ o poslovnim informacijama iz inozemstva. Ako je riječ o prikupljanju i distribuciji poslovnih informacija s domaćeg područja, u tim državama je sustav oslonjen na sigurnosne službe orijentirane na područje djelovanja u vlastitoj zemlji. Iz tog razloga iznenađuje križanje sigurnosnih službi iz ponuđenog odgovora predstavnika prve institucije.

Prikupljene poslovne informacije izuzetno je važno pravovremeno dostaviti poslovnim subjektima pa je stoga bilo potrebno istražiti na koji način te poslovne informacije koje se prikupe stižu do gospodarstva. Četvrta državna institucija svojim je odgovorima pokazala da na tom području poduzima najviše. Iz prve institucije stiže izjava de se informacije prema gospodarstvu distribuiraju na sastancima koje zainteresirani subjekti izričito zatraže. U suvremenim demokratskim društvima osnovna svrha državnih institucija je da budu servis društva, pa se stoga nikako ne bi smjelo događati da te iste institucije gospodarskim subjektima, zahvaljujući kojima zapravo postoje, daju nekakve informacije samo ako in to netko izričito traži, nego bi trebale biti pokretač svih pozitivnih promjena.

Prije prikupljanja bitnih poslovnih informacija svakako je prvi korak utvrditi koje je to informacije potrebno prikupiti. Odgovori treće i četvrte institucije su logični te kažu da treba komunicirati s onima kojima nastojimo pomoći kako bismo znali koji su im problemi. Takav pristup je pozitivan jednako kao i pogled u inozemstvo kako bi se vidjelo što se tamo događa, što je tamo aktualno. Druga institucija nije ponudila nikakav odgovor na ovo pitanje, što vodi prema zaključku da uopće ne razmišljaju kakve bi informacije bile korisne građevinarstvu i gospodarstvu u cjelini.

Kako je važno poznavati stanje unutar vlastitog sustava, također je važno poznavati i stanje u okruženju. Stoga je bilo bitno utvrditi prikupljaju li se na organiziranom nivou i informacije iz okruženju naše zemlje, tj. informacije iz inozemstva. Kroz odgovore na ovo pitanje vidimo da se kroz određene državne institucije prikupljaju informacije značajne za naše gospodarstvo te da te institucije imaju određenu logistiku koja omogućava prikupljanje takve vrste podataka. To bi na državnome nivou trebalo iskoristiti i nadograditi njihove sustave kako bi, po uzoru na primjere u Europi i svijetu, što bolje funkcionirala centralna agencija ili ured u koji bi se slijevale sve informacije ovakve vrste. Osnovna prednost koja govori u korist takvog sustava je ta da bi svi zainteresirani gospodarski subjekti znali da na jednome mjestu mogu dobiti sve potrebne informacije i koje je to točno mjesto. Ako se u inozemstvu prikupe poslovne informacije značajne za naše gospodarstvo, važno ih je proslijediti u RH. Analizirajući odgovore vidimo da državne institucije koje su u prethodnom odgovoru izjavile da sustavno prikupljaju poslovne informacije iz inozemstva i ovdje odgovaraju da te informacije sustavno prosljeđuju u RH.

Sljedeće pitanje treba dati direktan odgovor postoji li u RH na državnom nivou jedan središnji ured ili agencija u koju se šalju prikupljene informacije iz ureda organiziranih na raznim lokacijama diljem svijeta koje su predmet interesa našeg gospodarstva. Iz treće institucije dobiven je korektan i iskren odgovor kako na državnoj razini u RH ne postoji ovakav središnji ured, jer ako bi on postojao, ne bi imao svrhe ako za njega ne znaju odgovorne osobe unutar ključnih državnih institucija. Analizirajući ostale odgovore vidljivo je da su predstavnici nekih državnih institucija pokušali uljepšati stanje odgovorima kako nemaju točnih saznanja ili kako ne znaju postoji li takav središnji ured. Tijekom intervjua u prvoj instituciji, ovlaštena osoba je čak tri puta mijenjala stav oko odgovora na ovo pitanje, dok je ovlaštena osoba u drugoj instituciji tvrdila da takav središnji ured postoji unutar MVEP-a koji su, usput rečeno, tijekom intervjua tvrdili da nemaju takav središnji ured te da ne znaju da li on postoji na državnoj razini. Dobiveni odgovori nas ponovno vraćaju na ključni zaključak kako u Republici Hrvatskoj na državnom nivou ne postoji središnji ured ili agencija kojoj je zadatak pokrivanje ovog područja.

Sve navedeno zapravo pokazuje da stanje područja upravljanja poslovnim informacijama na državnom nivou nije na visokoj razini. Gornji zaključci su istraživanje usmjerili prema tome prati li netko, na razini državnih institucija, koliko su korisne informacije koje se njihovim kanalima dostavljaju gospodarstvu te da li su gospodarski subjekti ostvarili konkretne dobiti služeći se tim informacijama prilikom donošenja strateških odluka koje obilježavaju njihovo poslovanje. Analizirajući odgovore vidimo da oni variraju od onih koji kažu da se takvi konkretni pokazatelji uopće ne prate, do takvih odgovora koji kažu da je gospodarstvo imalo koristi od informacija koje mu država na ovaj način distribuira. Nakon analiziranja ankete i razgovora nametnuo se drugi zaključak, a to je da zapravo nitko na državnoj razini na osnovi opipljivih pokazatelja ne prati rezultate rada ovog sustava.

Sljedeće logično pitanje koje se nametnulo bilo je o tome što odgovorne osobe unutar državnih institucija misle o modelu sustava upravljanja poslovnim informacijama koji u RH funkcionira na državnoj razini, te da li isti, kroz rezultate koje postiže, opravdava svoje postojanje. Odgovarajući na ovo pitanje prva, druga i četvrta državna institucija diplomatski su odgovorile kako postojeći sustav pokazuje određene pozitivne rezultate, ali ima mjesta 
za njegova poboljšanja. Odgovor iz treće institucije bio je da sustav upravljanja poslovnim informacijama na državnoj razini u RH postoji samo na razini statističkih podataka, a nikako ne na operativnoj razini.

Idući upit koji se nametnuo je upit o tome prikupljaju li se poslovne informacije o bonitetu gospodarskih subjekata koji ulaze na naše tržište. Analiza odgovora je potvrdila da ne postoji zajednički kriterij na nivou državnih institucija niti suglasje oko većine pitanja na području upravljanja informacijama, kao ni formalna procedura koja utvrđuje kako to činiti. To se jasno vidi iz toga što jedna institucija tvrdi da se provjeravaju boniteti svih investitora koji ulaze na područje $\mathrm{RH}$, bile u pitanju investicije u javnom ili privatnom sektoru, drugi kažu da se provjeravaju samo investitori u javnom sektoru, a treći da se boniteti investitora koji ulaze na naše tržište provjeravaju povremeno, od slučaja do slučaja. Najlošije stanje pokazuje odgovor iz prve institucije koji kaže da nemaju saznanja o tome provjerava li netko bonitete potencijalnih investitora, ali to opravdavaju time da zapravo to ni ne trebaju znati jer nije u njihovoj nadležnosti.

Ravnodušan stav unutar institucija pokazan je i kod propitivanja razine zadovoljstva načinom i stupnjem primjene sustava upravljanja poslovnim informacijama koji u RH funkcionira na državnoj razini. U većini državnih institucija su ponovno diplomatski odgovarali kao i na neka ranija pitanja. Pravo stanje stvari oslikava odgovor treće institucije koji kaže da su nezadovoljni jer sustava nema, što je zapravo najveći problem gledajući državnu razinu $i$ to je ono što se treba bez odgode brzo promijeniti.

\section{Zaključak}

Nakon provedenog istraživanja stupnja primjene sustava upravljanja poslovnim informacijama u hrvatskim građevinskim poduzećima te istraživanja načina rada pojedinih državnih institucija na planu prikupljanja, analize i daljnjeg usmjeravanja poslovnih informacija prema gospodarskim subjektima u hrvatskom građevinarstvu, kroz središnji ured ili agenciju na državnom nivou, možemo reći da se suvremene metode koje podrazumijeva moderan sustav upravljanja poslovnim informacijama (Business Intelligence sustav) u Republici Hrvatskoj gotovo ne primjenjuju.

Osnovni razlog postojanja takvog stanja je nedovoljna obaviještenost gospodarskih subjekata s temeljnim odrednicama, svrhom i mogućnostima sustava ovakvog tipa. Sličan stupanj poznavanja sustava upravljanja poslovnim informacijama pokazalo je i istraživanje u državnim institucijama RH. Uz upotrebu sustava upravljanja poslovnim informacijama neraskidivo je vezan i segment sigurnosti poslovnih informacija koji je također bio predmetom ovog istraživanja. Prema pojedinim procjenama, poslovne tajne, odnosno povjerljive informacije vezane uz vlasnička pitanja i znanje koje posjeduju poslovni subjekti, čine u prosjeku više od $50 \%$ vrijednosti poslovnog subjekta. Analiza provedenog istraživanja je pokazala da se unutar poduzeća problematika sigurnosti informacija ne shvaća ozbiljno, što sasvim sigurno ima loše posljedice na uspješnost poslovanja hrvatskih građevinskih poduzeća. Naime, većina građevinskih poduzeća nema službu niti zaposlenike kojima je zadaća zaštita poslovnih informacija, niti imaju formalnu proceduru unutar poduzeća koja propisuje pravila ponašanja u odnosu na zaštitu poslovnih informacija. To znači da djelatnici tih poduzeća niti ne znaju kako bi se trebali ponašati radi zaštite informacija svoje tvrtke ali, što je još gore, nitko to od njih ni ne traži, što oslikava izuzetno loše stanje na tome području.

Analizirajući provedeno istraživanje također se uočava da ne postoji zajednički kriterij niti na nivou državnih institucija niti suglasje oko većine pitanja s područja upravljanja poslovnim informacijama. Na osnovi odgovora kroz intervju državnih institucija, može se reći da sustav upravljanja poslovnim informacijama na državnoj razini u RH postoji samo na razini statističkih podataka, a nikako ne na operativnoj razini.

\subsection{Preporuke za poboljšanje stanja na području upravljanja poslovnim informacijama}

Poduzeća mogu postati organiziranija i efikasnija samo ako imaju primjerene podatke i informacije o stanju unutar svog sustava, stanju na tržištu i o tome što radi konkurencija. Dakle, netko mora sustavno prikupljati takve javno dostupne informacije. U svakom poduzeću se već koristi neki oblik upravljanja poslovnim informacijama, a da toga nisu niti svjesni. Svaki zaposlenik koji pročita novine ili popriča s kolegama s istog područja interesa i djelovanja prikuplja informacije o tržištu i o poslovnom okruženju u kojem djeluje. 
Prikupljanje informacija je jedna od osnovnih faza procesa upravljanja informacijama, dok se ostale faze (sortiranje, analiziranje) pretežno izostavljaju ili nedovoljno koriste u današnjem poslovanju. Na osnovi rezultata istraživanja i gornjih zaključaka, preporuka gospodarskim subjektima je da:

- razvijaju oblike upravljanja poslovnim informacijama čije tragove sasvim sigurno imaju u okvirima svojih poslovnih sustava. Takve početne oblike potrebno je razvijati i dovesti na razinu modernih sustava za upravljanje poslovnim informacijama.

- prije uvođenja sustava upravljanja poslovnim informacijama u poduzeća reorganiziraju poslovne procese i implementiraju poslovno - informatičko rješenje.

- uzmu u obzir inozemna iskustva koja kažu da srednji menadžment više koristi sustave upravljanja poslovnim informacijama, dok top-menadžment sve informacije koje mu trebaju najčešće dobiva "servirane". Vodeći se time, treba konstantno raditi na edukaciji srednjeg ranga upravljačke strukture kako bi se osigurala što bolja implementacija sustava u svakodnevno poslovanje.

- vode računa o razvijanju svijesti o integraciji u poslovanje i svakodnevnoj primjeni sustava upravljanja poslovnim informacijama.

- svakako u svoje poslovne sustave integriraju službu sa osposobljenim zaposlenicima kojima će osnovna zadaća biti zaštita poslovnih informacija. Također je važno na razini gospodarskog subjekta utvrditi formalnu proceduru koja propisuje pravila ponašanja u odnosu na zaštitu poslovnih informacija.

Uvažavajući rezultate istraživanja, preporuka državnim institucijama je da:

- se provede ujednačavanje kriterija na nivou državnih institucija te postigne suglasje oko pitanja iz područja upravljanja poslovnim informacijama;

- se na državnoj razini uspostavi ozbiljno ustrojena organizacijska cjelina tj. središnji ured ili agencija čiji će rezultati biti ravnopravni središnjim sustavima na državnoj razini koji su zaduženi za tematiku upravljanja poslovnim informacijama u gospodarski razvijenim zemljama;

- se mora shvatiti da je najveća prepreka uvođenju centralnog sustava za upravljanje informacijama na državnome nivou, a samim time i integriranju sustava upravljanja poslovnim informacijama u poslovanje gospodarskih subjekata, relativna nezainteresiranost državne uprave, budući da država nema konkurencije te pojedine odgovorne osobe nemaju osjećaj težine svakodnevne tržišne utakmice;

- se na razini državnih institucija ne može tolerirati ravnodušan odnos prema problematici upravljanja poslovnim informacijama, naročito nakon spoznaje pozitivnih europskih i svjetskih iskustava na ovome području;

- suradnju između odgovarajućih državnih institucija podignu na višu razinu.

\section{Literatura}

[1] Dedijer, S.: Business intelligence 1999, Prva hrvatska konferencija o pribavljanju, organiziranju i uporabi poslovnih informacija, Zavod za poslovna istraživanja, Zagreb, 1999.

[2] Konferencija Strateški i nacionalni Business Intelligence 2003, Infoforum, Zagreb, 2003.

[3] Javorović B., Bilandžić M.: Poslovne informacije i business intelligence, Golden marketing, Tehnička knjiga, Zagreb, 2007.

[4] Panian Ž.; Klepac, G.: Poslovna inteligencija, Masmedia, Zagreb, 2003.

[5] Liautaud, B.; Hammond, M.: e-Poslovna inteligencija, Prudens Consilium, Varaždin, 2006.

[6] Novak, M.: Upravljanje informacijama u građevinskom poslovnom sustavu, magistarski rad, Građevinski fakultet Sveučilišta u Zagrebu, Zagreb, 2011. 